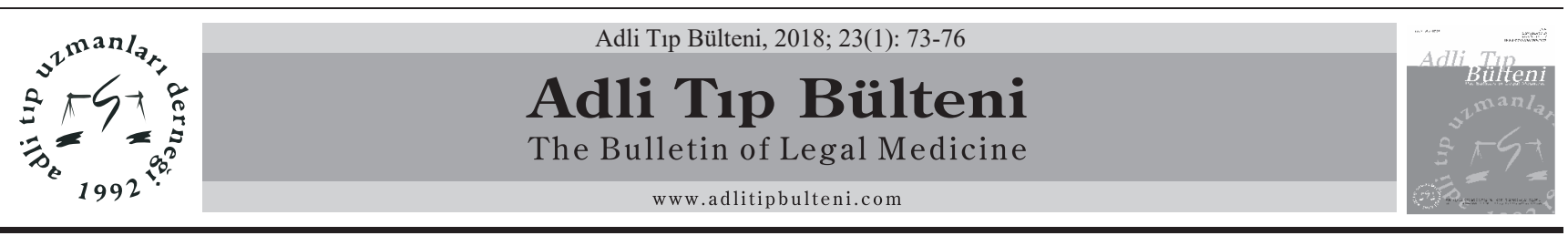

\title{
Car Accident Due to Horse Crossing the Motorway: Two Case Reports
}

\section{Taşıt Yoluna Çıkan At Sebebiyle Meydana Gelen Trafik Kazası: İki Olgu Sunumu}

\author{
Serbülent Kılıç ${ }^{1}$, Gürol Cantürk ${ }^{2}$ \\ ${ }^{1}$ Bursa Yüksek İhtisas Eğitim ve Araştırma Hastanesi, Adli Tıp Bölümü, Bursa \\ ${ }^{2}$ Ankara Üniversitesi Tıp Fakültesi Adli Tıp Anabilim Dalı, Ankara
}

\begin{abstract}
Basic Commercial Court in Ankara wanted a report from our department of forensic medicine about two injury cases due to animal vehicle collision. The reports should include the disability rate and the duration of unfunctionality. After the examination, we prepared the reports. Both vehicle collisions happened due to free ranging horse crossing the motorway. Both cases had different types of injury due to trauma. Vehicle collision due to horse crossing the motorway is rarely met in Turkey. Our aim to present the current two cases is investigation of injuries of animal related collision and makes forensic medicine specialists pay attention to the subject of preparing reports about such cases.

Our first case is a man that had upper extremity and facial injury. He uses prosthesis due to ear amputation. He has a scar tissue on the right side of his face and left forearm. The other case is three-years-old boy that had cranial bone fracture and cranial hematoma. He has also hemiparesis of the right side of body. Both cases have neurologic sequels but they have no psychiatric sequels.

In literature, animal vehicle collisions involve lots of animal species such as kangaroo, deer, camel and moose. Animal vehicle collision involving the horses is rarely met. Forensic medicine specialists should state the causal link between traumatic events and disabilities in order to help justice.
\end{abstract}

Keywords: Animal Vehicle Collision; Death; Disability; Horse; Injury; Motorway.

\section{Özet}

Ankara Asliye Ticaret Mahkemesi Adli Tıp Anabilim Dalımızdan trafik kazası nedeniyle yaralanan iki olgu ile ilgili rapor hazırlanmasını talep etmektedir. Hazırlanacak raporun olgulara ait maluliyet oranını ve iş göremezlik süresini içermesi istenmektedir. Yapılan incelemelerin ardından raporlar hazırlandı. Her iki olgunun travma sebebiyle farklı türde yaralanması mevcuttu. Taşıt yoluna çıkan atların neden olduğu trafik kazalarına Türkiye'de nadir olarak rastlanmaktadır. Bahsi geçen iki olgumuzu sunma amacımız; hayvan iştirakli trafik kazasına bağ $l_{1}$ yaralanmalarının incelenmesi ve adli tıp uzmanlarının bu tür olgular hakkında rapor hazırlanması konusuna dikkatinin çekilmesidir.

İlk olgumuz üst ekstremitesinden ve yüzünden yaralanan erişkin yaşta bir erkekti. Olgumuz kulak ampütasyonu nedeniyle protez kullanmaktaydı. Olgumuzun yüzünün sağ bölümünde ve sol önkolunda skar dokusu bulunmaktaydı. Diğer olgumuz, kazada kraniyal kemik kırığı ve hematom gelişen üç yaşında erkek çocuğuydu. Olgumuzun vücudunun sağ yarısında hemiparezi gelişmişti. Her iki olgumuzda nörolojik sekeller bulunmasına rağmen psikiyatrik sekel bulunmamaktaydı.

Literatürde kanguru, geyik, deve ve sığın geyiği gibi birçok farklı türde hayvanın iştirak ettiği trafik kazası bulunmaktadır. Ancak atların dahil olduğu trafik kazası literatürde nadir olarak bulunmaktadır. Adli tıp uzmanları adalete yardımcı olmak için, travmatik olaylar ile bunların neticesinde oluşmuş maluliyetler arasındaki illiyet bağını kurmalıdır.

Anahtar Kelimeler: Hayvan İștirakli Trafik Kazası; Ölüm; Maluliyet; At; Yaralanma; Taşıt Yolu.

\section{Introduction}

Vehicle collisions cause financial loss, injuries and deaths worldwide. The number of Animal Vehicle Collision (AVC) was 626 in 2014 in Turkey (1). In the United States, 210 human deaths were reported due to AVC between the years of 1995-2008 (2). In Europe, 300 deaths and 30.000 injuries in $500.000 \mathrm{AVC}$ were reported annually (3).

Corresponding Author: Serbülent Kılıç

Bursa Yüksek İhtisas Eğitim ve Araştırma Hastanesi, Adli Tip Bölümü, Bursa

E-mail: kilicserbulentmd@gmail.com

Received: 11.05.2016 Revision: 15.06.2016 Accepted: 18.07.2016
Many animal species are exposed to AVC. Animal species that exposed to AVC vary from country to country; for instance; deer in the United States; moose in Europe and Canada; camels in Saudi Arabia (4). In a study, in Sweden, it is reported that, in 1990's, nearly 5000 moose and 25.000 elks were exposed to AVC every year (5).

In our study, medical situation of two cases who were injured due to AVC including horses, are explained. Horse crossing the motorway is rarely met and it is of great value. Forensic medicine specialist prepares the report about people who are exposed to AVC. Our aim to present the current two cases is investigation of injuries in such cases and makes forensic medicine specialists pay attention while preparing reports about AVC cases. 


\section{Case 1}

Basic Commercial Court in Ankara asked a report from our department of forensic medicine about an injury case due to AVC. The report should include the disability rate and the duration of un-functionality. The first case is a 43-year-old male who was examined one year later AVC. His car hit a horse, which crossed the motorway suddenly, while he was sitting at the rear seat without wearing a seat belt. His right ear was amputated. Our case had a temporal bone fracture. In our examination, we found out that he was right-handed and had no psychopathology. Our case had prosthesis of right ear and peripheral facial paralysis on right, diameters of $11 \times 5 \mathrm{~cm}$ graft scar in the left wrist, diameters of $11.5 \times 9 \mathrm{~cm}$ graft scar in right femoral region, ankylosis of left shoulder and wrist joint. Also, his left arm and forearm muscles strengths were 4/5 (Figure 1 and 2).

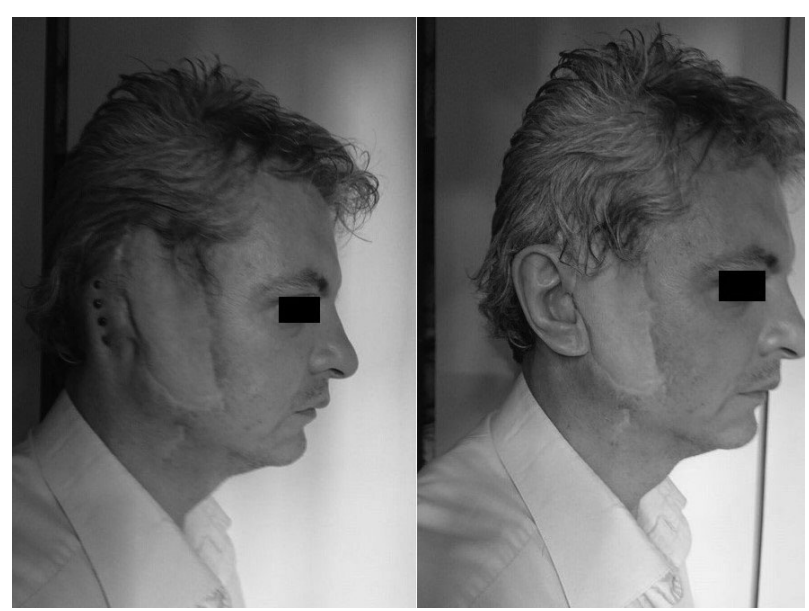

Figure 1. Prosthesis of right ear of the patient.

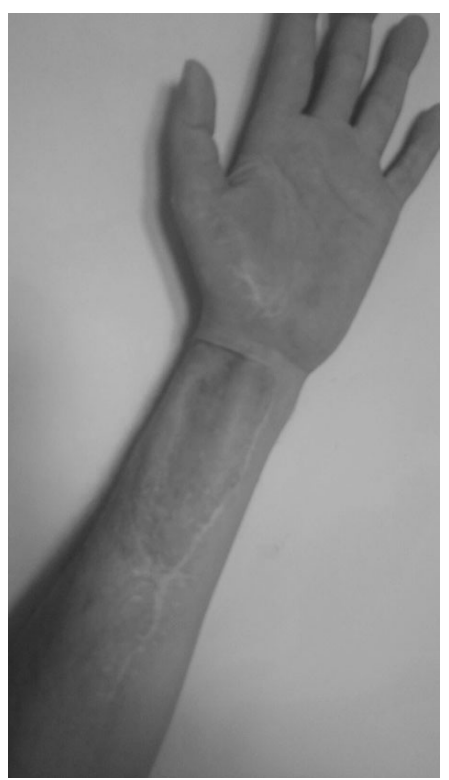

Figure 2. Graft scar tissue on left wrist of the patient.
In the report, which was prepared by the university hospital on the collision day it was stated that he applied emergency due to vehicle accident. Our case had a surgery for right temporal bone fracture at the same day. $\mathrm{He}$ had damaged tendons of second and third fingers and second finger bone fracture in the left hand. Facial nerve and tissues on the right side of his face and dura mater were defected.

In a report, which was prepared by the university hospital three months after the collision day it was stated that his right ear was amputated and he had no hearing loss. Our case had some depression symptoms but he had not enough treatment to make psychiatric diagnose. Partial axonal injury on his left brachial plexus was detected. His ulnar nerve was damaged. His disability rate was 53\% with these findings above.

In another report, which was prepared by the university hospital eighteen months after the collision day it was stated that his 2nd, 3rd, 4th, 5th fingers of left hand had ankylosis. The same report included partial axonal injury electromyogram findings of the left brachial plexus.

While the report was being prepared in our department; facial nerve paralysis, ear amputation, left arm paresthesia, ankylosis of left hand finger were considered. Finally, it was concluded that disability rate was $35,2 \%$ and the duration of unfunctionality was nine months in the report.

\section{Case 2}

The second case is 3-year-old male who was examined eighteen months after the AVC. The car hit a horse, which crossed the motorway suddenly, while he was sitting on his mother's lap on the front passenger seat without wearing a seat belt. His mother explained that her son had an AVC due to a horse crossing the motorway. He had a head trauma, an auditory deficiency on the left. Our case was driven to a training and research hospital. He had one surgery. Our case could not remember the collision exactly. He had normal anal external muscle reflex but still using diaper. Our case had hemiparesis on the right side of body.

In our examination, we found out that he was righthanded and he had no psychopathology. He had diameters of $20 \times 1 \mathrm{~cm}$ in pearl color, hair follicle free, swollen scar in the left occipito-frontal region of the head (Figure 3). Also, his upper and lower extremity muscles of the right side of the body strength were $4 / 5$ and he had no dysarthria (Figure 4). He could walk with a limp. Our case became unbalanced while he was crouching. 


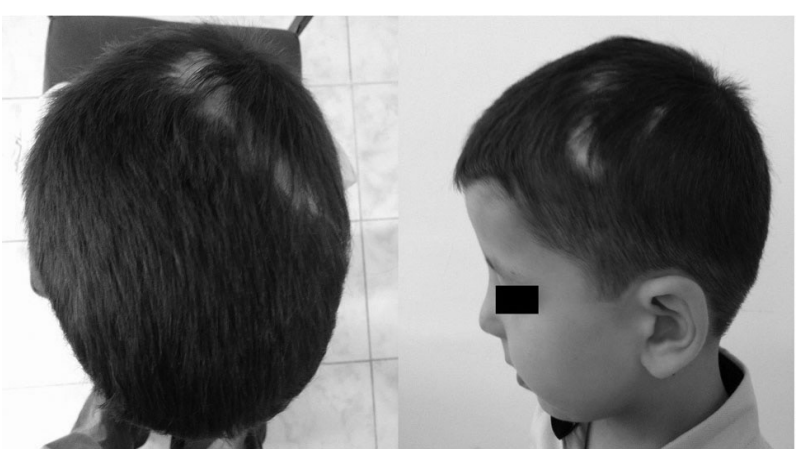

Figure 3. Scar tissue on the parietooccipital region of the patient.

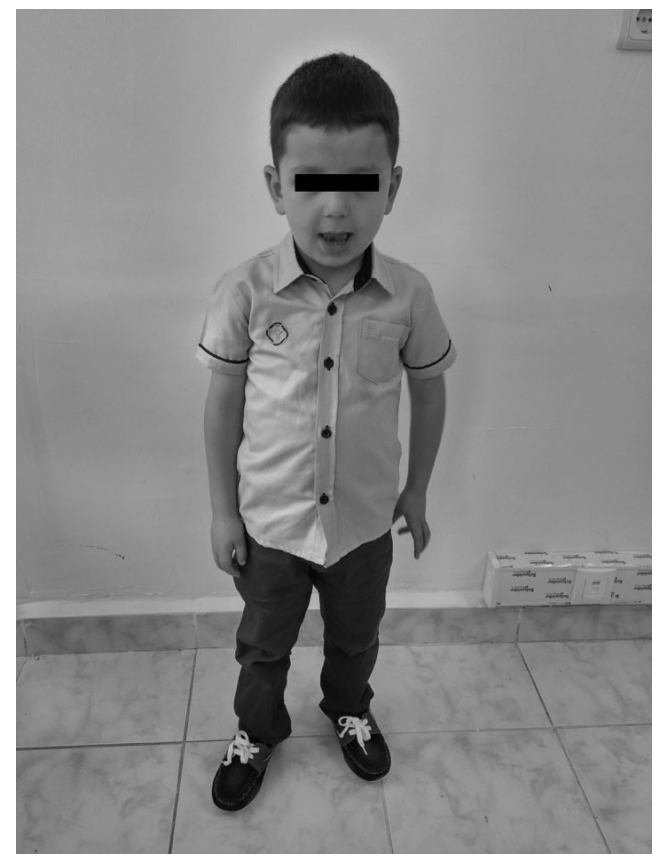

Figure 4. Hemiparesis of the right side of the patient's body

In the report, which was prepared by a training and research hospital on the collision day it was stated that he applied emergency due to vehicle accident. He had a cranial bone fracture with hematoma and stayed hospital for rehabilitation program.

In a report, which was prepared by the same hospital six months after the collision day it was stated that he had hemiparesis of the right side of the body and his disability rate was $51 \%$ with this finding.

In another report which was prepared by a university hospital nineteen months after the collision day it was stated that he had no hearing loss.

While the report was being prepared in our department; sequel of head trauma was considered. Finally, it was concluded that disability rate was $32,3 \%$ and the duration of unfunctionality was six months in the report.

\section{Discussion}

Vehicle collision due to horse crossing the motorway is rarely met. But it can cause several injuries. Both of the two vehicle collisions that we present above happened due to horses crossing the motorway. The rate of AVC incidence can change according to geographic region, season of the year, time of the day and distance of the motorway to the residential area.

Not only AVC threats animal and human life but also it causes financial loss. If a moderate sized animal is exposed to AVC, it causes approximately 1500 American Dollars of financial loss (6). In the United States, AVC including elks causes almost one billion American Dollars of financial loss annually (7). In a study about vehicle collision involving deer, this type of collisions causes almost 30.000 people injured per a year (8).

Our both cases had AVC involving horses, which are big mammalians and livestock animals. In a study about road trauma involves almost 1400 AVC cases, revealed that rate of AVC involving horses was $11 \%$ (9). It is found that the rate of the AVCs which need hospitalization was $1 \%$ in all crashes which need hospitalization in Australia (9).

The people who exposed to AVC may have injury in many regions of the body. Males are exposed to AVC rather than females as in all kinds of trauma. In a study which involves 46 people who had AVC due to kangaroos, reported that nearly $54 \%$ of the patients were injured from head and face. Nearly $57 \%$ of the patients were injured in the upper extremity. $90 \%$ of the AVC was occurred at night. $70 \%$ of the AVC cases were male in gender (5). In our study both cases were male and had head trauma and these findings are compatible with the literature (10). In contrast, in another study about animal-caused injuries, suggested that females were exposed more than males to the horse-related injuries (11). The age of most injured people was in the second decade was reported (11). In our study both cases were not in second decade and this finding are not compatible with the literature (11).

In a study about horse-related injuries, documented that most common injury patterns were head and upper limb traumas (12-14). On the other hand, neurological injury was reported as the most serious injury type (12). In our study, both cases had head trauma and neurological sequels and these findings are compatible with the literature (12). Skull, rib, thoracic spine, upper and lower extremity fractures, multiple traumas, maxillofacial trauma were reported in horse-related injuries $(11,13,14)$. Kicking was reported as the most common injury type of horse related injuries $(13,14)$. 
AVC involving horses can causes many of injury types. After the vehicle hits the animal, the vehicle may roll over the passengers within. This type of crash can cause multiple body traumas including head traumas. Animal may hit, scratch and kick the people in the car during the collision. If the sacrificed animal was a big mammalian like horse, cattle or kangaroo, severe amount of damage on the vehicle and increased human mortality could be expected. In a horse-related injury many of injury mechanisms can be seen. The animal related injury case can be dragged, crushed, trampled, kicked, butted, bitten, scalped, lacerated or abraded (15). Weight and size of animal is significant factor of AVC injuries. On the other hand, prevention techniques of road safety are of vital importance. Wearing seatbelt and driving a vehicle has airbags, bull bars and other safety equipment may be protective.

Our both cases were injured in AVCs due to free ranging horse crossing the motorway. Vehicle collision due to horse crossing the motorway is rarely met in our country. Horse related collisions may cause severe injuries such as neurological sequels and deaths were revealed by this study and literature review. Forensic medicine specialists have a significant role about this type of criminal cases as a reporter. Forensic medicine specialists have to know exactly all injury patterns of AVC on the human body. Examination of dead or alive AVC cases can have many findings which are hard to distinguish from other trauma types. From this point of view, forensic medicine specialists should state the causal link between traumatic events and disabilities while preparing the expert report. Our aim to present the current two cases is investigation of injuries of AVC and makes forensic medicine specialists pay attention to the subject of preparing reports about such cases.

In conclusion, forensic medicine specialists should know all the characteristics of injury types of vehicle collisions also, AVC exactly. Such cases are rarely met in common. Forensic medicine specialists ought to be aware of AVC cases while preparing the expert report.

\section{References}

1. Trafik Kazaları Özeti. Trafik Güvenliği Dairesi Başkanlığı, http://www.kgm.gov.tr/SiteCollectionDocuments/KGMdocuments/Trafik/TrafikKazalariOzeti2014.pdf Access date:24.02.2018

2. Sullivan JM. Trends and characteristics of animal-vehicle collisions in the United States. J Safety Res. 2011; 42: 9-16. DOI: 10.1016/j.jsr.2010.11.002.

3. Bruinderink GWTA G, Hazebroek E. Ungulate Traffic Collisions in Europe. Conserv Biol. 1996; 10: 1059-67. DOI: 10.1046/j.1523-1739.1996.10041059.x

4. Rowden P, Steinhardt D, Sheehan M. Road crashes involving animals in Australia. Accid Anal Prev. 2008; 40:186571. DOI: 10.1016/j.aap.2008.08.002.

5. Seiler A. Predicting locations of moose-vehicle collisions in Sweden. J Appl Ecol 2005; 42: 371-82. DOI: 10.1111/j.1365-2664.2005.01013.x

6. Malo JE, Suarez F, Diez A. Can we mitigate animal-vehicle accidents using predictive models? J Appl Ecol. 2004; 41: 701-710. DOI: 10.1111/j.0021-8901.2004.00929.x

7. Mastro LL, Conover MR, Frey SN. Deer-vehicle collision prevention techniques. Human-Wildlife Conflicts Spring. 2008; 2(1): 80-92.

8. Hothorna T, Müllerb J, Heldd L, Möste L, Mysterud A. Temporal patterns of deer-vehicle collisions consistent with deer activity pattern and density increase but not general accident risk. Accid Anal Prev. 2015; 81: 143-152. DOI: 10.1016/j.aap.2015.04.037

9. Attewell R, Glase K. Bull Bars and Road Trauma. ATSB Road Safety Research Report CR200. ISBN: 0642255504 9780642255501, Canberra, 2000.

10. Abu-Zidan FM, Parmar KA, Rao S . Kangaroo-related motor vehicle collisions. J Trauma. 2002; 53(2): 360-3.

11. Björnstig U, Eriksson A, Ornehult L. Injuries caused by animals. Injury. 1991; 22(4): 295-8. DOI: 10.1016/00201383(91)90009-4

12. Cripps RA. Horse-related injury in Australia. Australian Injury Prevention Bulletin. 2000; 24:1-20.

13. 13. Yildız M, Durukan P. Hayvanlara Bağlı Yaralanmalar. Firat Tip Derg. 2005; 10(1): 25-26.

14. Gönüllü H, Karadaş S, Güner S, Aydın İ. Ülkemizin Doğusunda Van ve Çevresinde Hayvanlarla İlişkili Yaralanmaların Analizi. İzmir Eğitim ve Araştırma Hastanesi T1p Dergisi. 2013;17:112-116.

15. Silver JR. Spinal injuries resulting from horse riding accidents. Spinal Cord. 2002; 40(6): 264-271. 